\title{
Analysis of the Effect of Marketing Mix 7P on Purchase Decisions at Sentra Snack Stores
}

\author{
Ivana Tanjung \\ UD. Sentra Snack \\ ivana tanjung@yahoo.co.id \\ https://doi.org/10.37715/rmbe.v1i2.2421
}

\begin{abstract}
This study examines the analysis of marketing mix (7P) effect to buying decision at Sentra Snack Store. Marketing mix (7P) are product, price, place, and promotion, people, process, and physical evidence. The main theory used is Theory of Reasoned Action by Fishbein and Ajzen (1975). The method used by this research is a quantitative research method, where the data is measured numerically and used Structural Equation Modeling with Partial Least Square. Theprogram used SmartPLS 3.3.3. The research was held at Sentra Snack Store, located in Surabaya with seventy samples of Sentra Snack Store customers. The results are Product and Price have a significant effect to Buying Decisions at Sentra Snack Store, while Promotion, Place, People, Process, and Physical Evidence do not. These results can be used as a basis for developing related strategies because they will further affect the company's sales and profit turnover.
\end{abstract}

Keywords - Marketing Mix, Product, Price, Promotion, Place, People, Process, Physical Evidence, Buying Decision.

\section{Introduction}

One of the food and beverage business sectors that continues to grow is snacks. Sentra Snack is a snack shop located in Surabaya. Established in 2015, and sells snacks at a price of Rp. 3,000.00. Snacks sold include a variety of chips, biscuits, chocolate, and nuts. With the affordable prices offered, many consumers are repurchases who buy for resale. Due to the Coronavirus pandemic in 2020, sales turnover at the Sentra Snack store decreased significantly. Costs normally incurred have been kept to a minimum, but not effective enough to increase net profit.

In an effort to analyze the causes of the decline in sales, aspects of the store were investigated, such as product, price, location, and so on. These aspects are summarized in the concept of the marketing mix (7P). The concept initially only consisted of 4Ps, namely product, price, place, and promotion. Along with the times, businesses no longer only sell products, but also must be able to have good service and brand development. The current $4 \mathrm{P}$ marketing mix has increased to $7 \mathrm{P}$ with elements of people, process, and physical evidence. The results of the study can be used as input to add insight to the owner of the Sentra Snack Store in order to know and analyze what factors influence consumer purchasing decisions at the Sentra Snack Store in order to increase sales turnover.

\section{Literature Review}

\subsection{Previous Research}

Carolina et al. (2021) examined the "Pengaruh Marketing Mix (7P) dan Perilaku Konsumen Terhadap Keputusan Pembelian Produk Healthy Food Bar di Malang”. The results of the research from 100 respondents showed that the marketing mix variables (product, price, distribution channel, promotion, people, process, physical environment) and consumer behavior (environmental, individual, psychological factors) simultaneously had a significant effect on purchasing decisions for HFB products. The study used variables similar to this study so that it was used as a reference.

Christine (2017) examines the "Analisis Pengaruh Marketing Mix (7P) terhadap Minat Beli Ulang Konsumen (Studi pada House of Moo, Semarang)". The purpose of this study was to determine how much influence the marketing mix (7P) has on consumers' repurchase intention to the House of Moo. The results showed that all of the marketing mix variables (7P), had a positive effect on consumer purchasing decisions at the House of Moo, but there was one variable that was not significant for purchasing decisions, namely the process variable. 
Silaningsih and Utami (2018) examines the "Pengaruh Marketing Mix terhadap Minat Beli Konsumen pada Usaha Mikro Kecil dan Menengah (UMKM) Produk Olahan Makanan Ringan”. The method used is the survey method, the form of research used in verification and descriptive research. The results showed that product, price, place, and promotion had a simultaneous effect on consumer buying interest. Partially, price and product have an effect on consumer buying interest, while promotion and place have no influence on consumer buying interest.

\subsection{Theoretical basis}

\subsubsection{Theory of Reasoned Action (TRA)}

Ajzen and Fishbein (1975, as cited in Mahyarni, 2013) state that the basic assumption of TRA is that humans are rational beings and use information systematically. This theory connects belief (belief), attitude (attitude), will (intention), and behavior (behavior). Intention to perform or not to perform a behavior is influenced by two basic determinants. The first relates to attitudes (attitude towards behavior), and the second relates to social influences, namely subjective norms.

\subsubsection{Buying Decision}

According to Tjiptono (2015) purchase decision is a process in which consumers recognize the problem, seek information about a particular product or brand and evaluate well each alternative can solve the problem, which then leads to a purchase decision. The indicators used to measure the purchasing decision variables according to Kotler and Keller (2012) as follows:

1. Product stability is a decision made by consumers, after considering various information that supports decision making

2. The habit of buying a product is the experience of the closest people (parents, siblings) in using a product.

3. Providing recommendations to others, is the delivery of positive information to others, so that they are interested in making a purchase.

4. Repurchase, is a continuous purchase, after consumers feel comfortable with the product or service received. 2.2.3. Marketing Mix

According to Kotler and Armstrong (2016), the marketing mix is the controllable variables that are combined to produce the expected response from the target market. Kotler and Keller (Kotler \& Keller, 2016) describe the variables of the marketing mix that are commonly used today are the 7Ps (product, price, promotion, place, people, process, physical evidence).

\subsubsection{Product}

According to Kotler and Keller (2016), a product is anything that can be offered to a market to satisfy a want or need, including physical goods, services, experiences, events, people, places, properties, organizations, information, and ideas. Limited to tangible or tangible objects, products also include services or services that companies offer to consumers.

\subsubsection{Price}

According to Ramli (2013), the notion of price is the relative value possessed by a product. This value is not a definite indicator that shows the amount of resources needed to produce the product.

\subsubsection{Promotion}

According to Tjiptono (2015) promotion is an element of the marketing mix that focuses on efforts to inform, persuade, and remind consumers of the company's brands and products. Utami (2016) mentions that there are three kinds of promotional tools that are often used, namely advertising, direct selling, and sales promotion.

\subsubsection{Place}

Place or location is defined as the physical structure of a store which is the main component that is seen informing the impression of a store that is carried out in placing its store and activities in providing service channels needed by consumers (Utami, 2016).

\subsubsection{People}

People or participants are employees of product or service providers or sales, or people who are directly or indirectly involved in the process (Kotler \& Keller, 2016). The people marketing mix is related to resource planning, job specifications, job descriptions, recruitment, employee selection, employee training, and work motivation (Adhaghassani, 2016). 


\subsubsection{Process}

According to Timpe (2004, as cited in Septian et al., 2014), process variables can be measured with the following indicators:

1. Flow of activities: This is the company's way of managing the flow of activities that are good and efficient in serving customers.

2. Task schedules: That is a regular schedule related to activities in the company, such as shop opening and closing schedules, cleaning picket schedules, and so on.

3. Routines: Includes the company's efforts to record and process activities that occur regularly, such as orders from regular customers.

\subsubsection{Physical Evidence}

According to Utami (2016), physical facilities are a determining factor in dominating the market share desired by the company, because market control can be achieved if the company gets a good position so that it can create a corporate image for its consumers. The dimensions of physical evidence according to Parasuraman et al. (1994, as cited in Fandy, 2011) include modern equipment, facilities that are visually attractive, employees who look neat and professional, things related to businesses that have visual appeal.

\section{Research Methods}

3.1. Analysis model

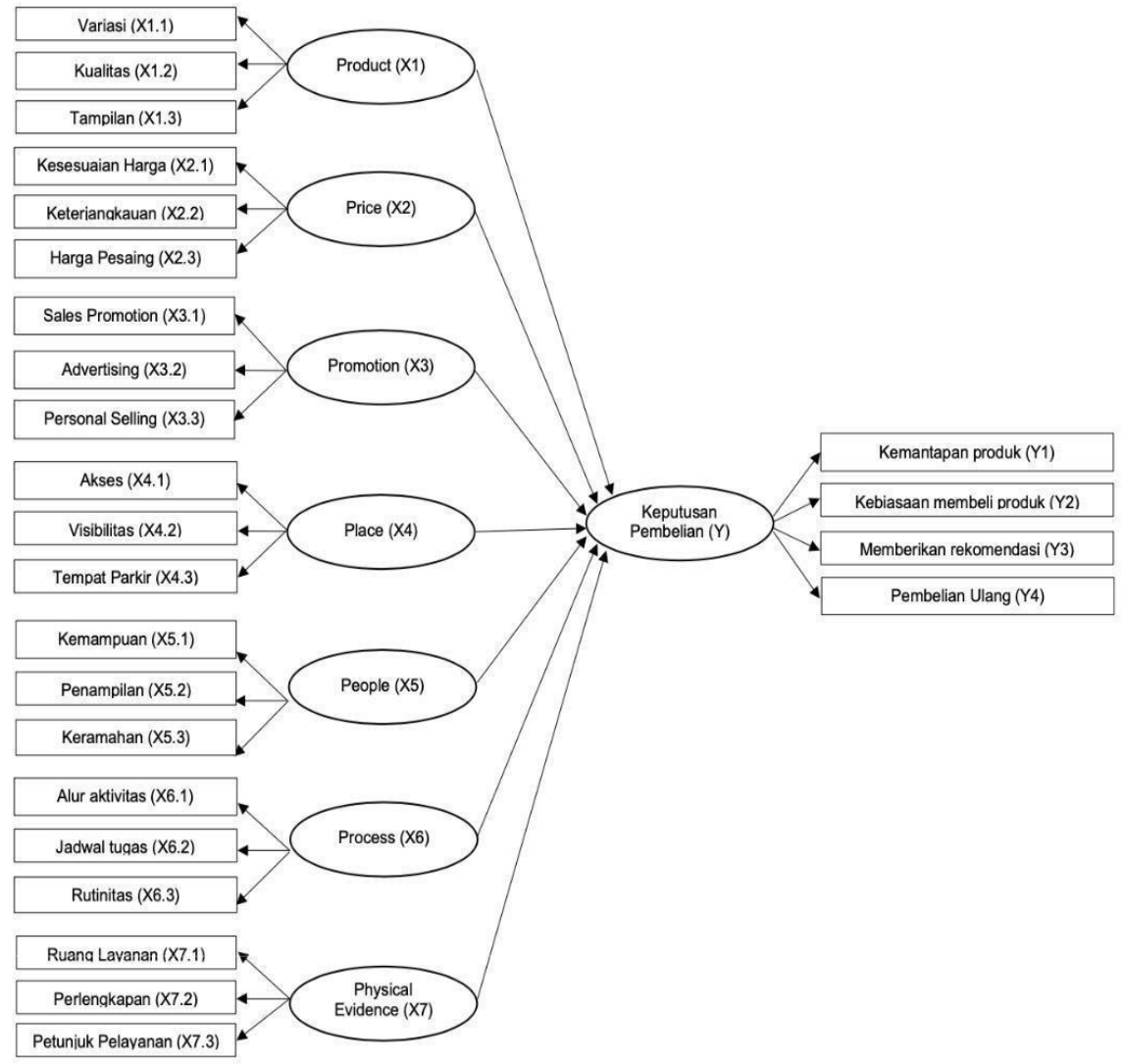

Figure 3.1. Research Analysis Model

\subsection{Research Hypothesis}

Based on the conceptual framework of the research above, the following hypotheses can be proposed:

- H1: Product influences purchasing decisions at Sentra Snack Stores.

- H2: Financial Attitude has a significant effect on Financial Behavior

- H3: Locus of Control has a significant effect on Financial Behavior

- H4: Risk Tolerance has a significant effect on Financial Behavior

- H5: Motivation has a significant effect on Financial Behavior

- H6: Mental Accounting has a significant effect on Financial Behavior 


\subsection{Research approach}

The method used by this research is a quantitative research method, where the data is measured numerically. Research will be conducted on individuals who have experience in making purchases at Sentra Snack stores. The time of the research is January to May 2021. The population in this study is Sentra Snack Store customers who have made purchases within the last year. The sample in this study amounted to 70 people. In this study there are no formative indicators, so a value of 10 times the number of structural paths that leads to a construct is used, which is 7 . Therefore, the number of samples needed is 70 respondents. The type of data used in this research is the type of quantitative data, namely the processing of data in the form of numbers or numbers using statistical calculations. The data sources used in this study consisted of 2 types, namely primary data sources and secondary data sources. The variables in this study consisted of 8, namely Product Price, Promotion, Place, People, Process, Physical Evidence, and Purchase Decision.

The data that has been collected from the consumer survey will then be analyzed using a quantitative approach. The method used is Structural Equation Modeling (SEM) - Partial Least Square (PLS) using SmartPLS software. The validity test was conducted to measure the ability of the indicators in the questionnaire to measure the desired concept. The validity test was carried out using the SmartPLS program with 2 kinds of tests, namely convergent validity and discriminant validity. Reliability testing is carried out to show the accuracy, consistency, and accuracy of a measuring instrument in the measurement. The reliability test was carried out using the SmartPLS program by taking into account the Cornbatch's Alpha value of the reliability statistic, with a value greater than 0.6 so that it can be concluded that the construct indicator is reliable and has met the reliability requirements.

\section{Result and Discussion}

\subsection{Characteristics of Respondents}

It can be concluded from the results of the questionnaire that the Sentra Snack Shop also has not attracted many consumers from the more mature age group, which indicates that the target market of the Sentra Snack Shop has not been achieved optimally because the two store locations are in an area surrounded by markets, shops, restaurants, and housing that is mostly inhabited by people aged 30 years and over. Based on the frequency of purchases, of the 70 respondents as many as 10 people or $14.3 \%$ make purchases once a month, 25 people or $35.7 \%$ make purchases 2-3 times per month, 21 people or 30\% make purchases 4-5 times per month, and 14 people or $20 \%$ make purchases more than 5 times per month.

\subsection{Descriptive statistics}

\subsubsection{Product Descriptive Statistics}

The output results of the validity of this research can be seen in the following table:

Table 4.1. Descriptive Statistics of Product Variables

\begin{tabular}{|c|l|c|c|c|}
\hline \multicolumn{1}{|c|}{ Statement } & Mean & Min & Max \\
\hline X1.1 & $\begin{array}{l}\text { Sentra Snack shop offers many variants of } \\
\text { snack products. }\end{array}$ & 4,786 & 3,000 & 5,000 \\
\hline X1.2 & $\begin{array}{l}\text { Sentra Snack shop offers products that have a } \\
\text { good taste. }\end{array}$ & 4,343 & 2,000 & 5,000 \\
\hline X1.3 & $\begin{array}{l}\text { The products offered by the Sentra Snack } \\
\text { Shop are of good quality. }\end{array}$ & 4,500 & 2,000 & 5,000 \\
\hline X1.4 & $\begin{array}{l}\text { Sentra Snack Store products have a good } \\
\text { appearance. }\end{array}$ & 4,543 & 1,000 & 5,000 \\
\hline \multicolumn{2}{|c|}{ Average Variable X1 Source: data processed (2020) } & 4,543 & 2,000 & 5,000 \\
\hline
\end{tabular}

The results of the research show that the highest average of the Promotion variable indicators with an average of 3,714 is in the statement: Employees master the Sentra Snack Store products and communicate well. These results indicate that in general the promos held by the Sentra Snack Shop are not effective, as can be seen from the low average rating of the respondents. Consumers are more familiar with and interested in Sentra Snack Store products from employee information than from promotions carried out. 


\subsection{2. $\quad$ Price Descriptive Statistics}

Table 4.2. Descriptive Statistics of Price Variables

\begin{tabular}{|c|c|c|c|c|}
\hline \multicolumn{2}{|r|}{ Statement } & Mean & Min & $\operatorname{Max}$ \\
\hline $\mathrm{X} 2.1$ & $\begin{array}{l}\text { Sentra Snack shop offers prices according to } \\
\text { quality }\end{array}$ & 4,671 & 2,000 & 5,000 \\
\hline $\mathrm{X} 2.2$ & $\begin{array}{l}\text { Sentra Snack shop offers affordable prices for } \\
\text { all people. }\end{array}$ & 4,757 & 3,000 & 5,000 \\
\hline $\mathrm{X} 2.3$ & $\begin{array}{l}\text { Sentra Snack Store prices compete with other } \\
\text { competitors. }\end{array}$ & 4,571 & 3,000 & 5,000 \\
\hline \multicolumn{2}{|r|}{ Average Variable X2 } & 4,666 & 2,667 & 5,000 \\
\hline
\end{tabular}

The results of the research shows that the highest average indicator variable Price with an average of 4.757 is in the statement: Sentra Snack Shop offers affordable prices for all people. From these results, it can be concluded that in terms of product prices, Sentra Snack Shops are generally still good, indicated by an average value of 4.666.

\subsubsection{Promotion Descriptive Statistics}

Table 4.3. Promotional Variable Descriptive Statistics

\begin{tabular}{|c|l|c|c|c|}
\hline \multicolumn{1}{|c|}{ Statement } & Mean & Min & Max \\
\hline X3.1 & $\begin{array}{l}\text { The promotion of Sentra Snack Shop products } \\
\text { attracts people to buy. }\end{array}$ & 3,457 & 1,000 & 5,000 \\
\hline X3.2 & $\begin{array}{l}\text { The existence of advertising on social media } \\
\text { makes you interested in knowing more about } \\
\text { Sentra Snack Store products. }\end{array}$ & 3,171 & 1,000 & 5,000 \\
\hline X3.3 & $\begin{array}{l}\text { Employees are familiar with Sentra Snack } \\
\text { Store products and communicate them well. }\end{array}$ & 3,714 & 1,000 & 5,000 \\
\hline \multicolumn{2}{|c|}{ Average Variable X3 } & 3,447 & 2,667 & 5,000 \\
\hline
\end{tabular}

Source: data processed (2020)

These results indicate that in general the promos held by the Sentra Snack Shop are not effective, as can be seen from the low average rating of the respondents. Consumers are more familiar with and interested in Sentra Snack Store products from employee information than from promotions carried out.

\subsubsection{Place Descriptive Statistics}

Table 4.4. Place Variable Descriptive Statistics

\begin{tabular}{|c|l|c|c|c|}
\hline \multicolumn{1}{|c|}{ Statement } & Mean & Min & Max \\
\hline X4.1 & $\begin{array}{l}\text { Sentra Snack shop has an easily accessible } \\
\text { location. }\end{array}$ & 4,571 & 2,000 & 5,000 \\
\hline X4.2 & $\begin{array}{l}\text { Sentra Snack shop has a location that is easily } \\
\text { visible from the roadside. }\end{array}$ & 4,614 & 3,000 & 5,000 \\
\hline X4.3 & $\begin{array}{l}\text { Sentra Snack shop provides adequate parking } \\
\text { space. }\end{array}$ & 4,314 & 3,000 & 5,000 \\
\hline \multicolumn{1}{|c|}{ Average Variable X4 } & 4,500 & 2,667 & 5,000 \\
\hline
\end{tabular}

Source: data processed (2020)

The results of the research shows that the highest average of the Place variable indicators with an average of 4.614 is in the statement: Sentra Snack Stores have a location that is easily visible from the side of the road. The location of the shop is quite visible to passers-by, but it needs to be used as input for the Sentra Snack Store that the parking area is not large enough for visitors so that at times when it is predicted to be crowded with visitors, additional parking spaces need to be prepared, one of which is by coordinating with neighbors in the surrounding environment to borrowed the front yard of the building.

\subsubsection{People Descriptive Statistics}

Table 4.5. People Variable Descriptive Statistics

\begin{tabular}{|c|l|c|c|c|}
\hline \multicolumn{1}{|c|}{ Statement } & Mean & Min & Max \\
\hline X5.1 & $\begin{array}{l}\text { Sentra Snack Store employees work } \\
\text { dexterously and efficiently. }\end{array}$ & 4,229 & 2,000 & 5,000 \\
\hline X5.2 & $\begin{array}{l}\text { The appearance of the Sentra Snack Store } \\
\text { employees is clean and tidy. }\end{array}$ & 3.700 & 1,000 & 5,000 \\
\hline X5.3 & $\begin{array}{l}\text { Sentra Snack Store employees provide } \\
\text { friendly and courteous service. }\end{array}$ & 4.043 & 2,000 & 5,000 \\
\hline \multicolumn{2}{|c|}{ Average Variable X5 } & 3,991 & 1,667 & 5,000 \\
\hline
\end{tabular}

Source: data processed (2020) 
From the People variable, it can be concluded that the employees have worked quite well, as seen from the overall average score of 3,991. However, the appearance of employees during work needs to be improved to be cleaner and neater.

\subsubsection{Process Descriptive Statistics}

Table 4.6. Process Variable Descriptive Statistics

\begin{tabular}{|c|l|c|c|c|}
\hline \multicolumn{1}{|c|}{ Statement } & Mean & Min & Max \\
\hline X6.1 & $\begin{array}{l}\text { The queue time at the Sentra Snack Shop is } \\
\text { relatively short. }\end{array}$ & 4,400 & 2,000 & 5,000 \\
\hline X6.2 & $\begin{array}{l}\text { Sentra Snack store has scheduled operating } \\
\text { hours. }\end{array}$ & 4.171 & 2,000 & 5,000 \\
\hline X6.3 & $\begin{array}{l}\text { Sentra Snack shop processes routine orders } \\
\text { quickly and responds. }\end{array}$ & 4,243 & 2,000 & 5,000 \\
\hline \multicolumn{2}{|c|}{ Variable Average X6 } & 4,271 & 2.000 & 5,000 \\
\hline
\end{tabular}

Source: data processed (2020)

The results of the research show that the highest average of the Process variable indicators with an average of 4,400 is in the statement: Queuing time at the Sentra Snack Store is relatively short. The lowest average was 4,171 in the statement: Sentra Snack Store has scheduled operating hours. It can be concluded that the service at the Sentra Snack Store cashier is fast so the queue time is not long, but the store's operating hours are less scheduled.

\subsubsection{Descriptive Statistics of Physical Evidence}

Table 4.7. Descriptive Statistics of Physical Evidence Variables

\begin{tabular}{|c|l|c|c|c|}
\hline \multicolumn{1}{|c|}{ Statement } & Mean & Min & Max \\
\hline X7.1 & $\begin{array}{l}\text { The service room at the Sentra Snack Shop is } \\
\text { clean and comfortable. }\end{array}$ & 4,286 & 3,000 & 5,000 \\
\hline X7.2 & $\begin{array}{l}\text { The service room at the Sentra Snack Store } \\
\text { is decent and adequate to serve consumers. }\end{array}$ & 4,371 & 2,000 & 5,000 \\
\hline X7.3 & $\begin{array}{l}\text { Snack shop display rack equipment is } \\
\text { adequate to serve consumers well. }\end{array}$ & 4,300 & 2,000 & 5,000 \\
\hline X7.4 & $\begin{array}{l}\text { Snack shop cashier equipment is adequate to } \\
\text { serve consumers well. }\end{array}$ & 4,557 & 3,000 & 5,000 \\
\hline X7.5 & $\begin{array}{l}\text { The service instructions at the Sentra Snack } \\
\text { Shop are self-explanatory. }\end{array}$ & 4.086 & 3,000 & 5,000 \\
\hline \multicolumn{2}{|l}{ Average Variable X7 } & 4,320 & 2.600 & 5,000 \\
\hline
\end{tabular}

Source: data processed (2020)

The results of the research show that the highest average indicator of the Physical Evidence variable with an average of 4,557 is in the statement: The cashier equipment of the Sentra Snack Shop is adequate to serve consumers. From these results, it is indicated that cashier equipment such as tables, tablet equipment, and cashier applications are functioning properly. On the other hand, service instructions are considered unclear due to buyers who do not understand the flow of purchasing goods.

\subsubsection{Purchasing Decision Descriptive Statistics}

Table 4.8. Descriptive Statistics of Purchase Decision Variables

\begin{tabular}{|c|l|c|c|c|}
\hline \multicolumn{1}{|c|}{ Statement } & Mean & Min & Max \\
\hline 1 & $\begin{array}{l}\text { I decided to buy Sentra Snack products } \\
\text { because I was interested in the stability of the } \\
\text { product }\end{array}$ & 4,614 & 2,000 & 5,000 \\
\hline Y2 & $\begin{array}{l}\text { I decided to buy Sentra Snack Store products } \\
\text { based on other people's experiences. }\end{array}$ & 3,343 & 1,000 & 5,000 \\
\hline Y3 & $\begin{array}{l}\text { I will recommend to others for Sentra Snack } \\
\text { Store products. }\end{array}$ & 4,314 & 2,000 & 5,000 \\
\hline Y4 & $\begin{array}{l}\text { I will make purchases of Sentra Snack Store } \\
\text { products repeatedly in the future. }\end{array}$ & 4,571 & 3,000 & 5,000 \\
\hline \multicolumn{2}{|c|}{ Y Variable Average } & 4,211 & 1,500 & 5,000 \\
\hline \multicolumn{2}{|c|}{ Source: data processed (2020) } \\
\hline \multicolumn{2}{|c|}{}
\end{tabular}

It can be concluded that the majority of respondents decided to buy Sentra Snack products because of their good personal experience about the stability of the product from various factors. On the other hand, the few respondents who bought from the experiences of others indicated that the experiences of others did not significantly influence one's purchasing decisions. From this, it can be concluded that although people who are around someone usually buy Sentra Snack Store products, if it is not as expected by that person, it can cause the purchase decision to not occur. 


\subsection{Data Processing with PLS-SEM}

\subsubsection{Purchasing Decision Descriptive Statistics}

After the research model is made complete with indicators, then the Algorithm Calculation is carried out on the SmartPLS software. For this research, all indicators are reflective.

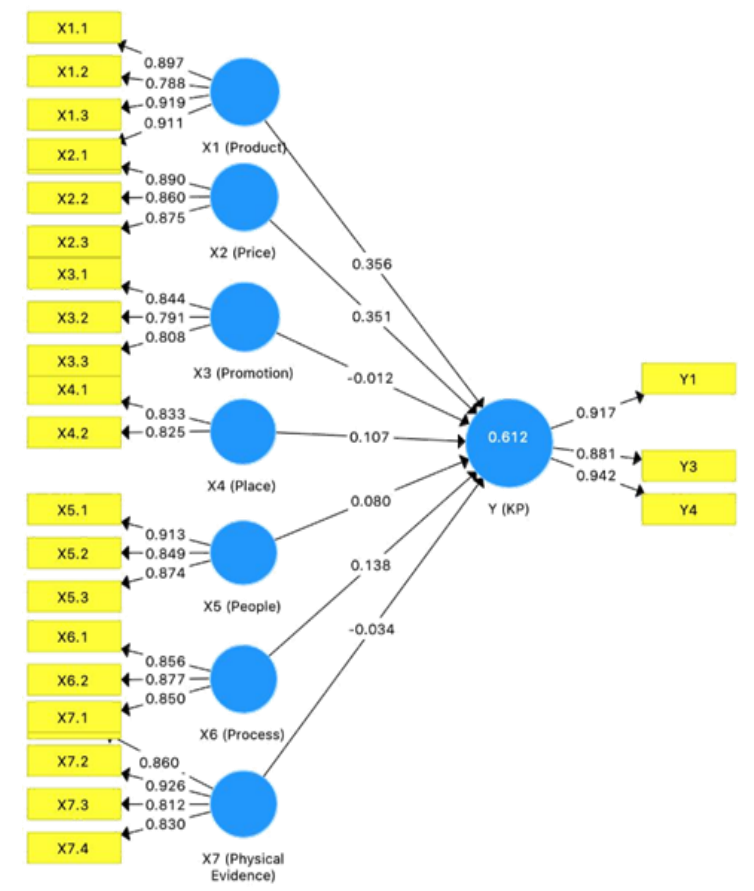

\subsubsection{Validity test}

Figure 4.1. Measurement and Structural Model PLS-SEM

1. Convergent Validity

A. Factor Loading

The factor loading test is carried out on each indicator and is said to be good if the value is greater than 0.7. If there is an indicator with a factor loading value below 0.7 , it will be deleted and retested.

Table 4.9. Second Outer Loading Validity Output

\begin{tabular}{|l|l|l|}
\hline Item & Outer Loading & Model Evaluation \\
\hline X1.1 & 0,897 & Good \\
\hline X1.2 & 0,788 & Good \\
\hline X1.3 & 0,919 & Good \\
\hline X1.4 & 0,911 & Good \\
\hline X2.1 & 0,890 & Good \\
\hline X2.2 & 0,860 & Good \\
\hline X2.3 & 0,875 & Good \\
\hline X3.1 & 0,844 & Good \\
\hline X3.2 & 0,791 & Good \\
\hline X3.3 & 0,808 & Good \\
\hline X4.1 & 0,833 & Good \\
\hline X4.2 & 0,825 & Good \\
\hline X4.1 & & \\
\hline X5.1 & 0,913 & Good \\
\hline X5.2 & 0,849 & Good \\
\hline X5.3 & 0,874 & Good \\
\hline X6.1 & 0,856 & Good \\
\hline X6.2 & 0,877 & Good \\
\hline X6.3 & 0,850 & Good \\
\hline X7.1 & 0,860 & Good \\
\hline X7.2 & 0,926 & Good \\
\hline X7.3 & 0,812 & Good \\
\hline X7.4 & 0,830 & Good \\
\hline & & \\
\hline
\end{tabular}




\begin{tabular}{|l|l|l|}
\hline X7.5 & & \\
\hline Y1 & 0,917 & Good \\
\hline Y2 & & \\
\hline Y3 & 0,881 & Good \\
\hline Y4 & 0,942 & Good \\
\hline
\end{tabular}

B. Average Variance Extracted (AVE)

The AVE value of each variable will be said to be good if it is greater than 0.5 , indicating that the indicators used are highly correlated.

Table 4.10. Average Variance Extracted (AVE)

2. Discriminant Validity

\begin{tabular}{|l|l|l|}
\hline Items & \multicolumn{1}{|c|}{ AVE } & Model Evaluation \\
\hline X1 & 0,775 & Good \\
\hline X2 & 0,766 & Good \\
\hline X3 & 0,664 & Good \\
\hline X4 & 0,687 & Good \\
\hline X5 & 0,773 & Good \\
\hline X6 & 0,742 & Good \\
\hline X7 & 0,737 & Good \\
\hline Y & 0,834 & Good \\
\hline
\end{tabular}

Validity test can be done by using cross loading. The results can be said to be good if they have a higher loading value for the measured construct than the loading value for other constructs.

\subsubsection{Reliability Test}

Measurement of reliability is measured by the value of Cronbach's Alpha and Composite Reliability.

Table 4.11. Reliability Test

\begin{tabular}{|l|l|l|}
\hline Items & Cronbach's Alpha & Composite Reliability \\
\hline $\mathrm{X} 1$ & 0,902 & 0,932 \\
\hline $\mathrm{X} 2$ & 0,847 & 0,908 \\
\hline $\mathrm{X} 3$ & 0,759 & 0,861 \\
\hline $\mathrm{X} 4$ & 0,576 & 0,780 \\
\hline X5 & 0,854 & 0,911 \\
\hline X6 & 0,826 & 0,896 \\
\hline X7 & 0,871 & 0,907 \\
\hline Y & 0,843 & 0,898 \\
\hline
\end{tabular}

From the results in Table 4.11 it can be concluded that overall the reliability of the variables is high, except for the value of Cronbach's Alpha of the Place variable which is still acceptable, but with the concept that the reliability is moderate.

\subsubsection{Structural Model Evaluation}

Tabel 4.12. R-Square

\begin{tabular}{|c|c|}
\hline Item & R-Square \\
\hline Purchase Decision (Y) & 0,652902 \\
\hline
\end{tabular}

The R-Square value of 0.652 indicates that the exogenous latent variable studied in this study has an influence on the Purchasing Decision variable of $65.2 \%$. It can be concluded that the R-Square of Purchase Decisions is moderate.

\subsection{Hypothesis testing}

Tabel 4.13. T-Statistics

\begin{tabular}{|l|r|r|}
\hline \multicolumn{1}{|c|}{ Item } & \multicolumn{1}{c|}{ Path Coef } & \multicolumn{1}{c|}{ T-Statistics } \\
\hline X1 (Product) -> Y(BD) & 0,356 & 2,515 \\
\hline X2 (Price) -> Y(BD) & 0,351 & 2,704 \\
\hline X3 (Promotion) -> Y(BD) & $-0,012$ & 0,101 \\
\hline X4 (Place) -> Y(BD) & 0,107 & 1,040 \\
\hline X5 (People) -> Y(BD) & 0,080 & 0,679 \\
\hline X6 (Process) -> Y(BD) & 0,138 & 1,271 \\
\hline X7 Physical Evidence) -> Y(BD) & $-0,034$ & 0,329 \\
\hline
\end{tabular}

From Table 4.13 it can be seen that the value of $\mathrm{t}$-statistics for the variables $\mathrm{X} 1$ product and $\mathrm{X} 2$ price is greater than 1.96 (significant), so it can be concluded that $\mathrm{H} 1$ and $\mathrm{H} 2$ can be verified. As for the variables X3 
promotion, X4 place, X5 people, X6 process, and X7 physical evidence, the T-statistics value is less than 1.96 so it can be said to be insignificant and $\mathrm{H} 3, \mathrm{H} 4, \mathrm{H} 5, \mathrm{H} 6$, and $\mathrm{H} 7$ are not proven true.

\section{Conclusions and Practical Implication}

\subsection{Conclusions}

After doing research, it can be proven that Product and Price have a significant effect on purchasing decisions. On the other hand, the variables Promotion, Place, People, Process, and Physical Evidence were not proven to have a significant effect on purchasing decisions at the Sentra Snack Store. This is an input for the Sentra Snack Store in developing related strategies because it will further affect the company's sales and profit turnover.

\subsection{Practical Implication}

Tabel 5.1. Practical Implication

\begin{tabular}{|l|l|l|}
\hline No & \multicolumn{1}{|c|}{ Research Findings } & \multicolumn{1}{c|}{ Suggestions for Snack Center Shops } \\
\hline 1. & $\begin{array}{l}\text { In terms of products, the taste is not in } \\
\text { accordance with consumer tastes so it } \\
\text { is not attractive to buy. }\end{array}$ & $\begin{array}{l}\text { Conduct a review of the product in the store so that it can record what } \\
\text { items are not selling well and how to fix them. }\end{array}$ \\
\cline { 3 - 3 } & $\begin{array}{l}\text { Comparison with several suppliers and replace product brands that } \\
\text { are less preferred with other brands. }\end{array}$ \\
\hline 2. & $\begin{array}{l}\text { Prices are offered still less } \\
\text { competitive. }\end{array}$ & $\begin{array}{l}\text { Perform benchmarking on a regular basis against several competitors in } \\
\text { order to review the company's position in the competition. }\end{array}$ \\
\cline { 3 - 3 } & $\begin{array}{l}\text { Provide added value to consumers, such as more attractive packaging, } \\
\text { good quality, promotions with prizes, and so on }\end{array}$ \\
\hline
\end{tabular}

\section{References}

Adhaghassani, F. S. (2016). Strategi bauran pemasaran (Marketing mix) 7P (Product, price, place, promotion, people, process, physical evidence) di Cherryka Bakery. Universitas Negeri Yogyakarta.

Caroline, E., Santoso, I., \& Deoranto, P. (2021). Pengaruh marketing mix (7P) dan perilaku konsumen terhadap keputusan pembelian produk Healthy Food Bar di Malang. Jurnal Manajemen Pemasaran, 15(1), 10-19. https://doi.org/10.9744/pemasaran.15.1.10-19

Christine, C., \& Budiawan, W. (2017). Analisis pengaruh marketing mix (7P) terhadap minat beli ulang konsumen (Studi pada House of Moo, Semarang). Industrial Engineering Online Journal, 6(1), 1-8.

Fandy, T. (2011). Pemasaran jasa. In Malang: Bayumedia. Malang: Bayumedia.

Fishbein, M., \& Ajzen, I. (1975). Belief, attitude, intention and behaviour: An introduction to theory and research. MA: Addison-Wesley.

Kotler, P., \& Amstrong, G. (2016). Principles of marketing (16th ed.). New Jersey : Pearson Prentince Hall.

Kotler, P., \& Keller, K. L. (2012). Manajemen pemasaran. Jilid 1 (13rd ed.). Jakarta: Erlangga.

Kotler, P., \& Keller, K. L. (2016). Marketing management (15th ed.). New Jersey: Pearson Education South Asia PTe Ltd.

Mahyarni, M. (2013). Theory of reasoned action dan theory of planned behavior (Sebuah kajian historis tentang perilaku). Jurnal EL-RIYASAH, 4(1), 13-23. https://doi.org/10.24014/jel.v4i1.17

Ramli, S. (2013). Bacaan wajib para praktisi pengadaan barang/jasa pemerintah. Jakarta: Visimedia.

Septian, N. B., Koentjoro, O. W., Aprilia, A., \& Siaputra, H. (2014). Pengaruh bauran pemasaran (produk, harga, tempat dan proses) terhadap minat beli ulang konsumen pada Warung Bu Darmi Siwalankerto Surabaya. Jurnal Hospitality Dan Manajemen Jasa, 2(2), 31-40.

Silaningsih, E., \& Utami, P. (2018). Pengaruh marketing mix terhadap minat beli konsumen pada Usaha Mikro Kecil dan Menengah (UMKM) produk olahan makanan ringan. Jurnal Sosial Humaniora, 9(2), 144-158. https://doi.org/10.30997/jsh.v9i2.1382

Tjiptono, F. (2015). Strategi pemasaran (Edisi 4). Jakarta: Andi.

Utami, C. W. (2016). Manajemen ritel strategi dan implementasi bisnis ritel modern di Indonesia (Edisi ke-3). Jakarta: Salemba Empat. 